\title{
Masks for at-risk population: nursing promoting biosafety in pandemic times
}

\author{
Máscaras para população de risco: a enfermagem promovendo \\ biossegurança em tempos de pandemia \\ Máscaras para poblaciones de riesgo: enfermería promoviendo \\ la bioseguridad en tiempos de pandemia
}

\author{
Patricia Abrahão-Curvo ${ }^{a}$ \\ Karina Dal Sasso Mendes ${ }^{b}$ \\ Angelina Lettiere-Viana ${ }^{a}$ \\ Maria Cândida de Carvalho Furtado ${ }^{a}$ \\ Thatiana Delatorrec \\ Susana Inés Segura-Muñoz ${ }^{\mathrm{a}}$
}

How to cite this article: Abrahão-Curvo P, Mendes KDS, Lettiere-Viana A, Furtado MCC, Delatorre T, Segura-Muñoz SI. Masks for at-risk population: nursing promoting biosafety in pandemic times. Rev Gaúcha Enferm. 2021;42(spe):e20200276. doi: https://doi.org/10.1590/19831447.2021.20200276 aniversidade de São Paulo (USP), Escola de Enfermagem de Ribeirão Preto, Departamento de Enfermagem Materno Infantil e Saúde Pública. Ribeirão Preto, São Paulo, Brasil.

b Universidade de São Paulo (USP), Escola de Enfermagem de Ribeirão Preto, Departamento de Enfermagem Geral e Especializada. Ribeirão Preto, São Paulo, Brasil.

Secretaria Municipal de Saúde de Ribeirão Preto, Departamento de Atenção à Saúde das Pessoas, Equipe Técnica da Atenção Básica. Ribeirão Preto, São Paulo, Brasil.

\section{ABSTRACT}

Objective: To describe a proposal for making and distributing masks for population in risk, with guidance on the stages of making them and the care in handling them based on the development of educational video and infographic.

Method: Experience report on the stages of the process of training people to make fabric masks for the population at risk, between March and June 2020, in a city in the interior of São Paulo.

Results:1,650 masks were made and distributed to vulnerable population groups from different contexts and tutorial video and infographic were elaborated and released to enable people to make their own masks with resources available at home.

Final considerations: It was possible to manufacture and distribute masks for the population at risk and develop educational actions to contain the disease, given the advance of confirmed cases and deaths by Covid-19, corroborating the role of nursing in health education.

Keywords: Masks. Nursing. Health education. Containment of biohazards. Covid-19.

\section{RESUMO}

Objetivo: Descrever proposta para confecção e distribuição de máscaras para populaç̧ão de risco, com orientações sobre as etapas de confecção e os cuidados no seu manuseio a partir do desenvolvimento de vídeo e infográfico educativos.

Método: Relato de experiência sobre as etapas do processo de capacitação de pessoas para confecção de máscaras de tecido para populaçãa de risco, entre março e junho de 2020, em município do interior paulista.

Resultados: Foram confeccionadas e distribuídas 1.650 máscaras para grupos populacionais de risco de diferentes contextos, elaborados e divulgados materiais instrucionais, como tutorial com vídeo explicativo e infográico para capacitar pessoas para confeccionarem suas próprias máscaras com recursos disponíveis no domicílio.

Considerações finais: Foi possível confeccionar e distribuir máscaras para população de risco e desenvolver ações educativas para a contenção da doença, dado o avanço dos casos confirmados e de mortes pela Covid-19, corroborando o papel da enfermagem na educação em saúde.

Palavras-chave: Máscaras. Enfermagem. Educação em saúde. Contenção de riscos biológicos. Covid-19.

\section{RESUMEN}

Objetivo: Describir propuesta de confección y distribución de máscaras para población en riesgo, con orientación sobre las etapas de elaboración y cuidados en su manejo con la elaboración de video e infográfico educativos.

Método: Relato de experiencia sobre las etapas del proceso de capacitación de personas para la confección de máscaras para poblaciones en riesgo, entre marzo y junio de 2020, en una ciudad del interior de São Paulo.

Resultados: Se confeccionaron 1.650 máscaras y se distribuyeron a grupos de riesgo de diferentes contextos, se elaboró y divulgó video tutorial e infográfico para que las personas puedan hacer sus propias máscaras con recursos disponibles en el hogar.

Consideraciones finales: Fue posible fabricar y distribuir máscaras para la población en riesgo y desarrollar acciones educativas para contener la enfermedad, dado el avance de casos confirmados y defunciones por Covid-19, confirmando el rol de la enfermería en la educación para la salud.

Palabras claves: Máscaras. Enfermería. Educación en salud. Contención de riesgos biológicos. Covid-19. 


\section{INTRODUCTION}

In the bicentennial celebration year of the birth of the precursor of nursing, Florence Nightingale, the world was taken by surprise by an emerging disease caused by the new SARS-CoV-2 (Severe Acute Respiratory Syndrome of Coronavirus 2) that triggered the Covid-19 (Coronavirus disease 2019) pandemic, first identified in China in December 2019. Covid-19 has spread to 191 countries, with high morbidity and mortality rates worldwide, including in Brazil(1).

Because of the speed at which this virus has spread, non-pharmacological measures have been recommended, such as respiratory etiquette, frequent hand washing, and social isolation, in order to reduce contamination among the general population and interrupt the Covid-19 cycle $^{(2)}$. In addition, the use of masks is indicated as a physical barrier. Despite these recommendations, there is a shortage of these inputs for individual and collective protection, as in the case of hospital masks for priority use among health workers. As specified in guidelines of the World Health Organization (WHO) $)^{(3)}$, in April 2020, the Brazilian Ministry of Health (MS) recommended the use of homemade cloth face masks by the general population as a physical barrier against contamination ${ }^{(3)}$.

Evidence has shown the lower efficiency of cloth masks compared to medical masks, so they are contraindicated for health workers. However, cloth masks are more efficient when made with hybrid fabrics (cotton, chiffon, or silk), especially with several layers, and their use is recommended as a general public health measure against Covid-19 contamination and transmission. Thus, the cloth mask can be effective depending on the fabric and the number of layers used, when appropriately adapted to the facial outline of the wearer, and has, therefore, been associated with non-pharmacological measures ${ }^{(4)}$.

Given the above and considering the potential social contribution of the university regarding the transfer of health-related knowledge, the guiding question was as follows: what precautions and recommendations are necessary for making cloth face masks?

Thus, this report aims to describe a proposal for making and distributing masks for the at-risk population, with guidelines on the sewing stages and precautions when handling the masks based on the creation of an educational video and infographic.

\section{METHOD}

This is an experience report conducted between March and June 2020, in Ribeirão Preto, state of São Paulo, Brazil. The municipality, in the northwest of the state of São Paulo, has 683,777 inhabitants, of which 110,088 are over 60 years old, which represents $16.1 \%$ of the population ${ }^{(5)}$. Different population groups can be defined as a risk group for Covid-19(6), according to possible complications and mortality rate, including the elderly, patients with chronic diseases, people with obesity, people who are bedridden, pregnant women and women in the postpartum, and people in conditions of social vulnerability (homeless).

A group of four faculty members and a nurse from the Ribeirão Preto School of Nursing of the University of São Paulo (EERP/USP) began making masks composed of three layers of 100\% tricoline-type cotton fabric as specified by scientific evidence ${ }^{(7)}$. Using donated fabric and trims and the help of six volunteer seamstresses, 620 masks were initially made and delivered.

In parallel, a request for approval of the extension project was submitted to and obtained from the Culture and Extension Commission of the EERP/USP, resulting in the supply of another 1,030 masks. These masks were delivered in nine stages to different at-risk groups selected with the Department of Primary Care ("DAB") of the Municipal Health Department ("SMS") of Ribeirão Preto.

Subsequently, three faculty members and three employees of the EERP/USP helped create and divulge educational material (tutorials with audiovisual and photographic resources) on how to make the cloth masks and precautions for use and handling to enable sustained production in the community, using materials available at home, according to recommendations of the $\mathrm{MS}^{(8)}$. A tutorial video was recorded on fabric mask making using an audiovisual device (Sony HXR MC 2500 camera, recorded in full HD 1080 pixels with direct audio capture), on the premises of the EERP/USP.

The tutorial video was produced using equipment and materials characteristically found in a home workshop (domestic sewing machine, base for cutting, fabrics, lines, patterns, scissors, trims, rubber bands) to reproduce the scenario for making masks. The video was edited with Adobe Premiere Pro software. Simultaneously, a photographic catalog was assembled to create the infographic, produced with the Pro version of Canva (www.canva.com), an online image and photo editor. In both productions, the step-by-step process 
for making cloth masks was demonstrated. In addition, an information booklet was produced with precautions for using and cleaning the mask.

The information produced during the realization of this project was recorded through photos and notes in field journals in order to count and track the number of people who received the masks, by means of partnerships with health care and social services provided to at-risk population groups. The television and print media was one of the communication channels also used to divulge the project and expand its reach. Two inserts were aired on public regional television news programs, totaling 7 minutes of exposure, and guidelines on mask making were published in a university newspaper, together with an educational infographic.

\section{RESULTS AND DISCUSSION}

In the scope of primary health care (PHC), anticipated social distancing measures in Ribeirão Preto prior to sustained transmission of the coronavirus helps to contain the spreading of the virus at the beginning of the pandemic. The recommendation to use face masks as protection by the MS and SMS was also fundamental ${ }^{(8)}$.

As a result of this initiative, 1,650 masks were made and distributed to at-risk population groups. Table 1 shows the stages of this distribution, according to the production and demand of the Department of Primary Care of the SMS.

Once made, the masks were sanitized, ironed, and packed in plastic bags with a booklet ${ }^{(9)}$ containing a summary of main precautions for correct use, handling, and care during their sanitization (Figure 1).
The combined efforts of the scientific community and the health services regarding social empowerment and self-care actions during the Covid-19 outbreak were fundamental to mitigate uncertainties caused by the Brazilian socio-political framework ${ }^{(10)}$.

The social vulnerability and lack of government policies that encouraged people to stay at home reinforced the need for protective masks that, knowingly, decrease the spread of droplets expelled by the nose or mouth of asymptomatic individuals that may circulate in the municipality.

In response to the proposed action, it was possible to produce instructional material that further encourages people to make their own cloth masks with materials they have at home. Thus, a video tutorial lasting 11 minutes and 32 seconds $^{(11)}$ and a two-page infographic (Figure 2) ${ }^{(12)}$ were produced and divided into seven steps for making masks of three layers of fabric. Both materials have been available on the EERP/USP website since April 2020(11-12). The educational materials were created to encourage the production and use of cloth masks according to basic specifications of breathability and filtration of viral particles, so as to potentiate their use and ensure the reduction of respiratory exposure to the novel coronavirus ${ }^{(13)}$.

The (re) configuration of social behaviors and the evolution of the Covid-19 pandemic in Brazil created the need to protect the community and divulge actions that promote self-care ${ }^{(14)}$. It was possible to stimulate social protagonism in the fight against the pandemic and arouse interest in the making and/or use of homemade masks as another form of intervention, especially for vulnerable populations. We believe that this action corroborated the visibility of nursing and the

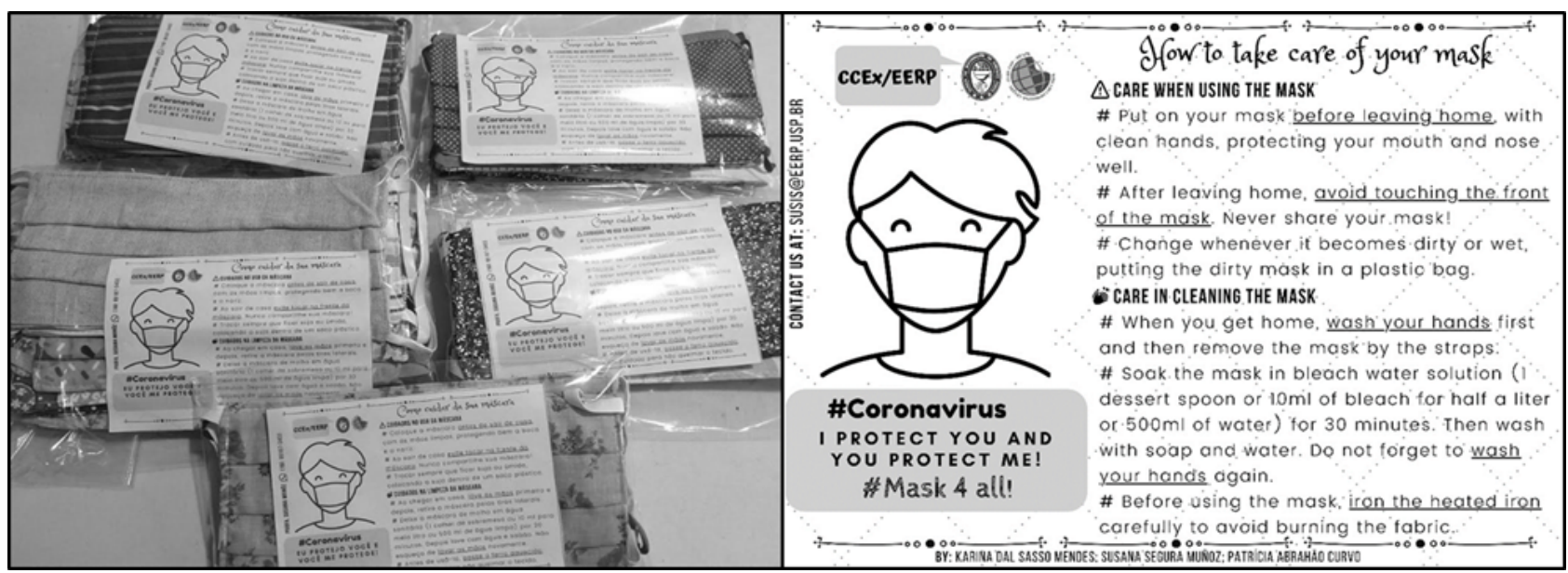

Figure 1 - Samples of cloth masks and image of the educational booklet containing mask use and hygiene information. Ribeirão Preto, SP, Brazil

Source: Mendes, Segura-Muñoz and Abraham-Curvo (2020) $)^{(9)}$ 
Table 1 - Cloth masks distributed to population groups at risk for Covid-19, made from March to June 2020. Ribeirão Preto, SP, Brazil

\begin{tabular}{|c|c|c|}
\hline Stage & At-risk population & $\begin{array}{l}\text { No. of } \\
\text { masks }\end{array}$ \\
\hline 1st stage & Bedridden elderly and people with risk comorbidities, their caregivers and family members & 620 \\
\hline 2nd stage & Bedridden elderly and people with risk comorbidities, their caregivers and family members & 300 \\
\hline 3rd stage & Bedridden elderly registered in the home assistance service of the SMS of Ribeirão Preto & 140 \\
\hline 4th stage & Pregnant and postpartum women at the Women's Health Reference Center ("MATER") & 100 \\
\hline 5th stage & Cleaning and security workers of the health education unit & 60 \\
\hline 6th stage & $\begin{array}{l}\text { Homeless people through the Limite Institute and the Municipal Social Welfare Secretariat of } \\
\text { Ribeirão Preto }\end{array}$ & 150 \\
\hline 7th stage & $\begin{array}{l}\text { Patients treated in philanthropic institutions that provide health care, such as the municipality's } \\
\text { backup hospital. }\end{array}$ & 100 \\
\hline 8th stage & Bedridden elderly and people with risk comorbidities, their caregivers and family members & 130 \\
\hline \multirow[t]{2}{*}{ 9th stage } & $\begin{array}{l}\text { Homeless people and vulnerable communities assisted by the "Street Clinic" of the SMS de } \\
\text { Ribeirão Preto }\end{array}$ & 50 \\
\hline & Total & 1,650 \\
\hline
\end{tabular}

Source: research data, 2020.

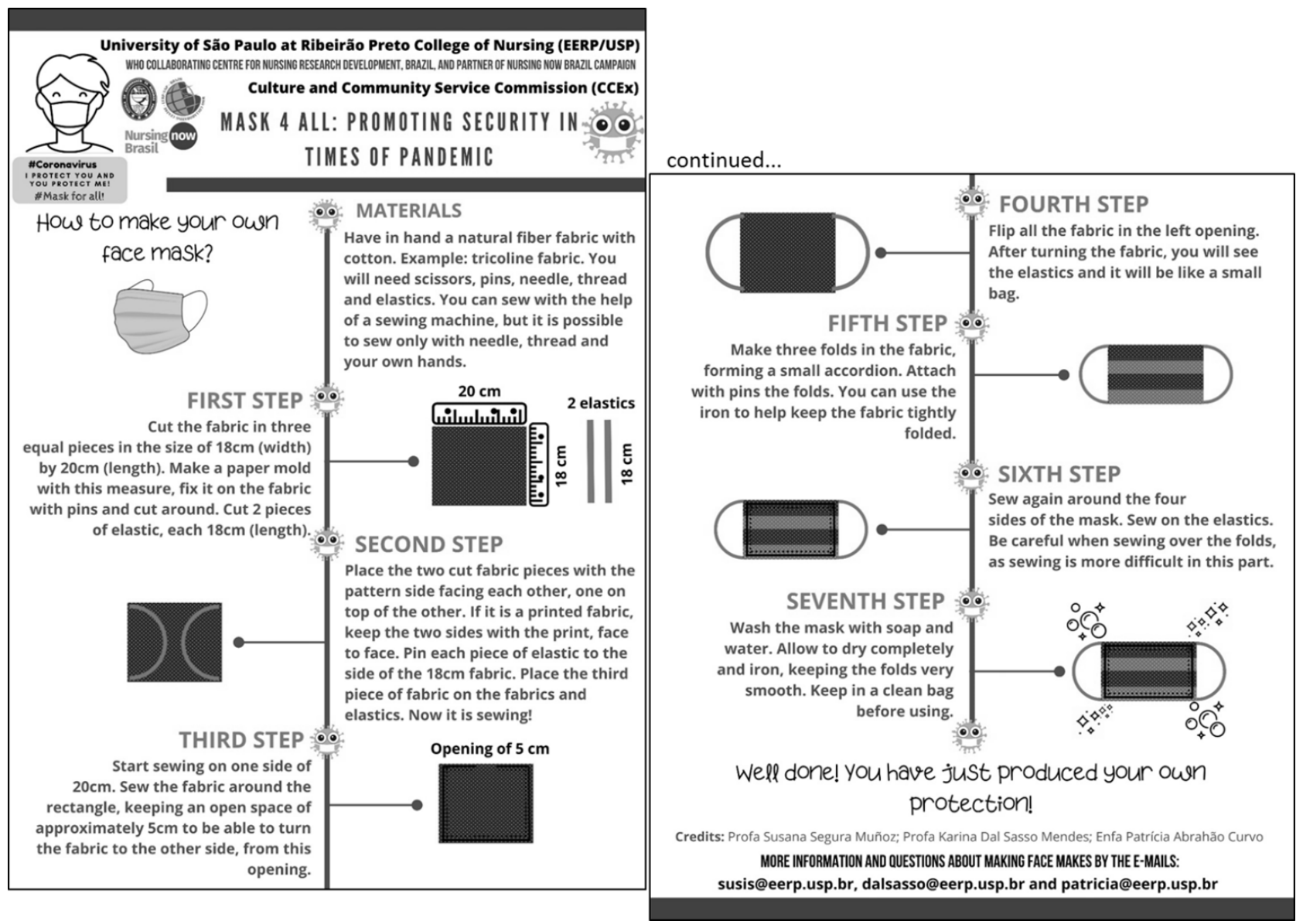

Figure 2 - Infographic with a step-by-step guide for the production of triple-layer cloth masks, April 2020. Ribeirão Preto, SP, Brazil Source: Segura-Muñoz, Mendes and Abraham-Curvo (2020)(2) 
dissemination of effective and innovative nursing practices, in line with the premises of the Nursing Now campaign ${ }^{(15)}$.

\section{FINAL CONSIDERATIONS}

It was possible to make and distribute masks for the at-risk population and develop educational actions to contain the risks. The limitation of this action is the lack of standardization of technical guidelines on the types of materials and the number of layers of cloth that would provide collective protection with retention of viral particles, the definition of which took longer than initially planned. Moreover, the availability of instructional materials (video and infographic) should be highlighted as a health education activity carried out by faculty members and nurses of the educational institution. The coordinated efforts of the educational institution, health services, and social welfare services were fundamental to distribute the masks to the population at risk and for the media coverage of the educational health care materials. In this way, it was possible to transcend the limits of the university walls and contribute to the municipality in the health care of groups at risk for Covid-19. Implications for professional practice include the greater visibility of nursing as a social practice due to the commitment of faculty members and nurses regarding health promotion and disease prevention, in the defense of life and health as a right, in an extremely critical public health scenario.

\section{$\square$ REFERENCES}

1. Johns Hopkins University \& Medicine. Covid-19 Dashboard by the Center for Systems Science and Engineering (CSSE) at Johns Hopkins University (JHU) Baltimore, Maryland: Johns Hopkins University \& Medicine; 2020 [cited 2020 Jun 10]. Available from: https://coronavirus.jhu.edu/map.html

2. Garcia LP, Duarte E. Nonpharmaceutical interventions for tackling the COVID-19 epidemic in Brazil. Epidemiol Serv Saúde. 2020;29(2):e2020222. doi: https:// doi.org/10.5123/s1679-49742020000200009

3. World Health Organization $(\mathrm{CH})$. Advice on the use of masks in the context of Covid-19: interim guidance. Geneva: WH0; 2020 [cited 2020 Jul 01]. p. 5. Available from: https://apps.who.int/iris/handle/10665/331693
4. Santos M, Torres D, Cardoso PC, Pandis N, Flores-Mir C, Medeiros R, et al. Are cloth masks a substitute to medical masks in reducing transmission and contamination? a systematic review. Braz Oral Res. 2020;34:e123. doi: https:// doi.org/10.1590/1807-3107bor-2020.vol34.0123

5. Governo do Estado de São Paulo (BR), Fundação Sistema Estadual de Análise de Dados. Perfil dos municípios paulistas [Internet]. São Paulo: Fundação SEADE; 2020 [cited 2020 May 12]. Available from: https://perfil.seade.gov.br/

6. Williamson EJ, Walker AJ, Bhaskaran K, Bacon S, Bates C, Morton CE, et al. Factors associated with COVID-19-related death using OpenSAFELY. Nature. 2020;584(7821):430-6. doi: https://doi.org/10.1038/s41586-020-2521-4

7. Bhattacharjee S, Bahl P, Chughtai AA, Maclntyre CR. Last-resort strategies during mask shortages: optimal design features of cloth masks and decontamination of disposable masks during the COVID-19 pandemic. BMJ Open Resp Res. 2020;7(1):e000698. doi: https://doi.org/10.1136/bmiresp-2020-000698

8. Ministério da Saúde (BR). Nota informativa no 3/2020 - CGGAP/DESF SAPS/ MS. [Dispõe sobre a utilização de EPIs e a confecção de máscaras caseiras] Brasília: Ministério da Saúde; 2020 [cited 2020 May 10]. Available from: http:// portal.antaq.gov.br/wp-content/uploads/2020/04/1586014047102-NotaInformativa.pdf

9. Mendes KDS, Segura-Muñoz SI, Curvo PA. Como cuidar da sua máscara [Internet]. Ribeirão Preto: EERP-USP; 2020 [cited 2020 Jun 10]. Available from: http://conteudosdigitais.eerp.usp.br/covid19/como_cuidar_da_sua_ mascara_facial_email.pdf

10. Oliveira AC. Challenges faced by nursing professionals in the COVID19 pandemic [editorial]. REME - Rev Min Enferm. 2020 [cited 2020 mai 12];24:e-1302. Available from: https://cdn.publisher.gn1.link/reme.org.br/pdf/en_e1302.pdf

11. Segura-Muñoz SI, Mendes KDS, Curvo PA, Alonso M, Romano WB. Máscara para todos: promovendo segurança em tempos de pandemia [video]. Ribeirão Preto: EERP-USP; 2020 [cited 2020 Jun 10]. Available from: https://www.youtube. com/watch?v $=h$ YnrGkJaP6Y

12. Segura-Muñoz SI, Mendes KDS, Curvo PA. Máscara para todos: promovendo segurança em tempos de pandemia [infographic]. Ribeirão Preto: EERP-USP; 2020 [cited 2020 Jun 10]. Available from: http://conteudosdigitais.eerp.usp.br/ covid19/projeto_mascara_para_todos_2020_email.pdf

13. Konda A, Prakash A, Moss GA, Schmoldt M, Grant GD, Guha S. Aerosol filtration efficiency of common fabrics used in respiratory cloth masks. ACS Nano. 2020;14(5):6339-47. doi: https://doi.org/10.1021/acsnano.0c03252

14. Hammerschmidt KSA, Santana RF. Health of the older adults in times of the COVID-19 pandemic. Cogitare Enferm.2020;25:e72849. doi: https://doi. org/10.5380/ce.v25i0.72849

15. Cassiani SHB, Lira-Neto JCG. Nursing perspectives and the Nursing Now Campaign [editorial]. Rev Bras Enferm. 2018;71(5):2351-2. doi: https://doi. org/10.1590/0034-7167.2018710501 
Abrahão-Curvo P, Mendes KDS, Lettiere-Viana A, Furtado MCC, Delatorre T, Segura-Muñoz SI

\section{- Acknowledgments:}

To the Committee on Culture and University Extension of the School of Nursing of Ribeirão Preto, University of São Paulo, for the financial support granted to the University Extension Project "Máscaras para todos: promovendo segurança em tempos de pandemia" (in English, "Masks for all: promoting safety in times of pandemic"), in Emergency Mode, within the framework of institutional actions to fight against Covid-19.

\section{- Authorship contribution:}

Conceptualization: Susana I. Segura-Muñoz, Patricia Abrahão-Curvo.

Data curation: Susana I. Segura-Muñoz, Patricia AbrahãoCurvo, Karina Mendes.

Formal analysis: Susana I. Segura-Muñoz, Patricia AbrahãoCurvo, Karina Mendes.

Acquisition of financing: Susana I. Segura-Muñoz, Patricia Abrahão-Curvo, Karina Mendes.

Research: Susana I. Segura-Muñoz, Patricia Abrahão-Curvo, Karina Mendes.

Methodology: Susana I. Segura-Muñoz, Patricia AbrahãoCurvo, Karina Mendes.

Project management: Susana I. Segura-Muñoz.

Resources: Susana I. Segura-Muñoz, Patricia Abrahão-Curvo, Karina Mendes.

Software: Karina Mendes.

Supervision:Susana I. Segura-Muñoz, Patricia Abrahão-Curvo. Validation: Susana I. Segura-Muñoz, Karina Mendes, Patricia Abrahão-Curvo.

Visualization: Susana I. Segura-Muñoz, Patricia AbrahãoCurvo, Karina Mendes.

Writing - original draft: Susana I. Segura-Muñoz, Patricia Abrahão-Curvo, Angelina Lettiere-Viana, Thatiane Delatorre. Writing - review and editing: Susana I. Segura-Muñoz, Patricia Abrahão-Curvo, Karina Mendes, Angelina LettiereViana, Maria Cândida Furtado, Thatiane Delatorre.

\section{- Corresponding author:}

Susana Inés Segura-Muñoz

Email: susis@eerp.usp.br

\section{Associate editor:}

Dagmar Elaine Kaiser

\section{Editor-in-chief:}

Approved: 12.03 .2020

Maria da Graça Oliveira Crossetti 